\title{
Besponsa (Inotuzumab Ozogamicin) pada Kasus Leukemia Limfoblastik Akut Relaps atau Refrakter pasien Dewasa
}

\author{
Hendra \\ Dokter Umum Puskesmas Dedai, Sintang, Kalimantan Barat
}

\section{Pendahuluan}

Leukemia Limfoblastik Akut (LLA) adalah penyakit keganasan yang diakibatkan oleh adanya mutasi somatik yang multistep pada sel progenitor limfoid. Meskipun cukup jarang terjadi pada orang dewasa, namun risiko meningkat seiring usia. Sebanyak $20 \%$ kasus dari LLA adalah dewasa. Sebagian kasus muncul pada anak, namun kematian terjadi lebih banyak pada dewasa. Prognosis LLA pada dewasa tergantung dari subtipe nya dan dapat memburuk dengan cepat tanpa tatalaksana yang tepat. Dibutuhkan update pengetahuan baru tentang tatalaksana LLA yang relaps ataupun refrakter. Pada tahun 2017, US Food and Drug Administration menyetujui Inotuzumab Ozogamicin sebagai terapi baru untuk kasus LLA relaps atau refrakter pada dewasa.

\section{Definisi LLA}

Leukemia Limfoblastik Akut (LLA) adalah penyakit keganasan yang diakibatkan oleh adanya mutasi somatik yang multistep pada sel progenitor limfoid yang kemudian berkembang menjadi berbagai stadium. LLA adalah penyakit keganasan yang berasal dari progenitor sel B atau sel T. ${ }^{1}$

\section{Etiologi dan Faktor Risiko LLA}

Penyebab LLA pada dewasa sebagian besar tidak diketahui. ${ }^{2}$ Inisiasi dan progresi menjadi LLA dipengaruhi oleh banyak mutasi yang mengubah fungsi selular, termasuk meningkatnya kemampuan self-renewal, perubahan dalam kendali proliferasi normal, blok terhadap diferensiasi, dan meningkatnya resistensi terhadap signal kematian (apoptosis). Kelainan dalam familial juga berpengaruh dalam proses perbaikan DNA. Walaupun demikian, pada sebagian besar kasus, tidak selalu ada etiologi yang jelas. Faktor risiko terjadinya LLA bisa berasal dari genetic dengan hiperploidi, faktor lingkungan seperti paparan radiasi, rokok, pestisida, ataupun alcohol. ${ }^{1}$

\section{Klasifikasi LLA ${ }^{3}$}

Klasifikasi LLA terdiri dari subtype secara imunologi, abnormalitas sitogenetikyang terjadi 
dan subtipe menurut French - American-British

Classificatio.

Tabel 1. Klasifikasi Leukemia Limfoblastik Akut (LLA)

\begin{tabular}{lcll}
\hline TABLE 97-2 & Classification of Acute Lymphoid leukemia (ALL) \\
\hline $\begin{array}{l}\text { Immunologic } \\
\text { Subtype }\end{array}$ & \% of Cases & FAB Subtype & Cytogenetic Abnormalities \\
\hline Pre-B ALL & 75 & L1, L2 & $\mathrm{t}(9 ; 22), \mathrm{t}(4 ; 11), \mathrm{t}(1 ; 19)$ \\
T cell ALL & 20 & L1, L2 & $14 \mathrm{q} 11$ or $7 \mathrm{q} 34$ \\
B cell ALL & 5 & L3 & $\mathrm{t}(8 ; 14), \mathrm{t}(8 ; 22), \mathrm{t}(2 ; 8)$ \\
\hline
\end{tabular}

Note: FAB, French-American-British classification.

\section{Epidemiologi LLA}

Acute Lymphoblastic Lekuemia (LLA) adalah keganasan yang tejadi pada $75 \%$ leukemia anak. Meskipun cukup jarang terjadi pada orang dewasa, namun risiko meningkat seiring usia. Sebanyak 20\% kasus dari LLA adalah dewasa. ${ }^{2}$ (IPDUI). Subtipe dari LLA penting dalam indikator prognostik survival pasien. ${ }^{4}$

American Cancer Society telah memperkirakan bahwa terdapat sebanyak 6020 kasus baru LLA di Amerika Serikat pada tahun 2014, dan terjadi 1440 kematian dari kasus LLA. Sebagian kasus muncul pada anak, namun kematian terjadi lebih banyak pada dewasa. ${ }^{1}$

\section{Diagnosis LLA}

Presentasi klinis LLA sangat bervariasi. Pada umumnya gejala klinis menggambarkan kegagalan sumsum tulang atau keterlibatan ekstramedular oleh sel leukemia. Akumulasi sel limfoblas di sumsum tulang menyebabkan kurangnya sel normal di darah perifer dan terkait dengan gejala anemia, infeksi dan perdarahan. Bisa juga ditemukan demam pada $50 \%$ pasien LLA. Anoreksia, nyeri tulang, hepatosplenomegali, limfadenopati, massa di mediastinum dapat juga ditemukan. Jika kondisi memberat, bahkan dapat melibatkan system saraf pusat ataupun organ lain seperti testis, retina, kulit, pleura, pericardium dan tonsil. ${ }^{2}$

Pada tahun 2017, College of American Pathologists and American Society of Hematology (CAP/ASH) mengeluarkan rekomendasi diagnosis LLA. Diagnosis LLA membutuhkan data lengkap klinis pasien, Complete Blood Count (CBC), differential leukosit, hapusan darah tepi,evaluasi morfologi Bone Marrow Aspiration (BMA) menunjukkan Adanya $\geq 20 \%$ limfoblast pada sumsum tulang, immunophenotyping, analisis kariotip dan genetik molekular. $^{5}$ 


\section{Terapi LLA ${ }^{1}$}

\section{Terapi Suportif}

Tatalaksana optimal pasien LLA membutuhkan perhatian khusus terhadap terapi suportif, termasuk tatalaksana darurat atau pencegahan terhadap komplikasi metabolik dan infeksi serta penggunaan rasional dari produk darah.

Tatalaksana suportif lainnya seperti pemakaian kateter, kendali rasa nyeri, dukungan psikososial untuk pasien serta keluarga sangat diperlukan.

\section{Terapi Anti Leukemia}

Karena LLA merupakan penyakit yang heterogen dengan berbagai subtioe, maka tidak ada pendekatan yang seragam terkait dengan terapinya. Dewasa ini, tatalaksana ditujukan pada subgroup tertentu.

\section{Induksi Remisi}

Tujuan pertama dari terapi adalah menginduksi terjadinya remisi komplit dan mengembalikan hematopoesis yang normal. Regimen induksi biasanya terdiri dari glukokortikoid (prednisone, prednisolone, atau dexamethasone), vincristine, dan L-asparaginase untuk anak-anak ataupun anthrax-cycline untuk pasien dewasa. Perbaikan dalam kempoterapi dan terapi suportif menghasilkan remisi komplit sekitar 98\% untuk anak-anak dan 85-90\% untuk pasien dewasa.

\section{Prognosis LLA ${ }^{2}$}

Tabel 2. Faktor Prognostik Leukemia Limfoblastik Akut (LLA)

\begin{tabular}{|c|c|}
\hline Karakteristik Pasien & Faktor P \\
\hline $\begin{array}{l}\text { Usia (tahun) } \\
\quad<30 \\
\quad \geq 30\end{array}$ & $\begin{array}{l}\text { Baik } \\
\text { Buruk }\end{array}$ \\
\hline $\begin{array}{l}\text { Jumlah Leukosit }\left(\times 10^{6} / \mathrm{mL}\right) \\
\quad<30.000 \\
\quad \geq 30.000(>100.000 \text { untuk sel T) }\end{array}$ & $\begin{array}{l}\text { Baik } \\
\text { Buruk }\end{array}$ \\
\hline $\begin{array}{l}\text { Immunophenotype } \\
\text { T-cell ALL } \\
\text { Mature B-cell ALL, early T-cell ALL }\end{array}$ & $\begin{array}{l}\text { Baik } \\
\text { Buruk }\end{array}$ \\
\hline $\begin{array}{l}\text { Sitogenetika } \\
\text { Kelainan 12p; } t(10 ; 14)(q 24 ; q 11) \\
\text { Normal; hyperploid } \\
\text { t(9;22), } t(4 ; 11), t(1 ; 19) \text {, hipoploid }\end{array}$ & $\begin{array}{l}\text { Baik } \\
\text { Sedang } \\
\text { Buruk }\end{array}$ \\
\hline $\begin{array}{l}\text { Respons Terapi } \\
\text { Remisi komplit dalam } 4 \text { minggu } \\
\text { Minimal residual disease persisten }\end{array}$ & $\begin{array}{l}\text { Baik } \\
\text { Buruk }\end{array}$ \\
\hline
\end{tabular}




\section{Besponsa (Inotuzumab Ozogamicin)}

Pada Agustus 2017, FDA menyetujui

(Inotuzumab Ozogamicin) Besponsasebagai

terapi untuk LLA pda dewasa. Terutama

digunakan untuk LLA tipe sel B yang relaps ataupun refrakter. ${ }^{6}$

\section{Cara Kerja Inotuzumab Ozogamicin}

Inotuzumab Ozogamicin adalah antibody

monoclonal manusia dengan ekspresi CD22 yang membawa agen sitotoksik calicheamicin. CD22 diekspresikan oleh sel blast leukemia sebanyak > 90\% pasien LLA. Inotuzumab Ozogamicin akan berikatan dengan reseptor CD22 sel B dan diinternalisasikan membentuk CD22-Antibody Drug Conjugate (ADC). Hal ini mengarah pada pelepasan dan aktivasi toksin calicheamicin. Pada nucleus, calicheamicin menyebabkan apoptosis dari sel target. ${ }^{7}$

Gambar : Mekanisme Kerja Inotuzumab Ozogamicin

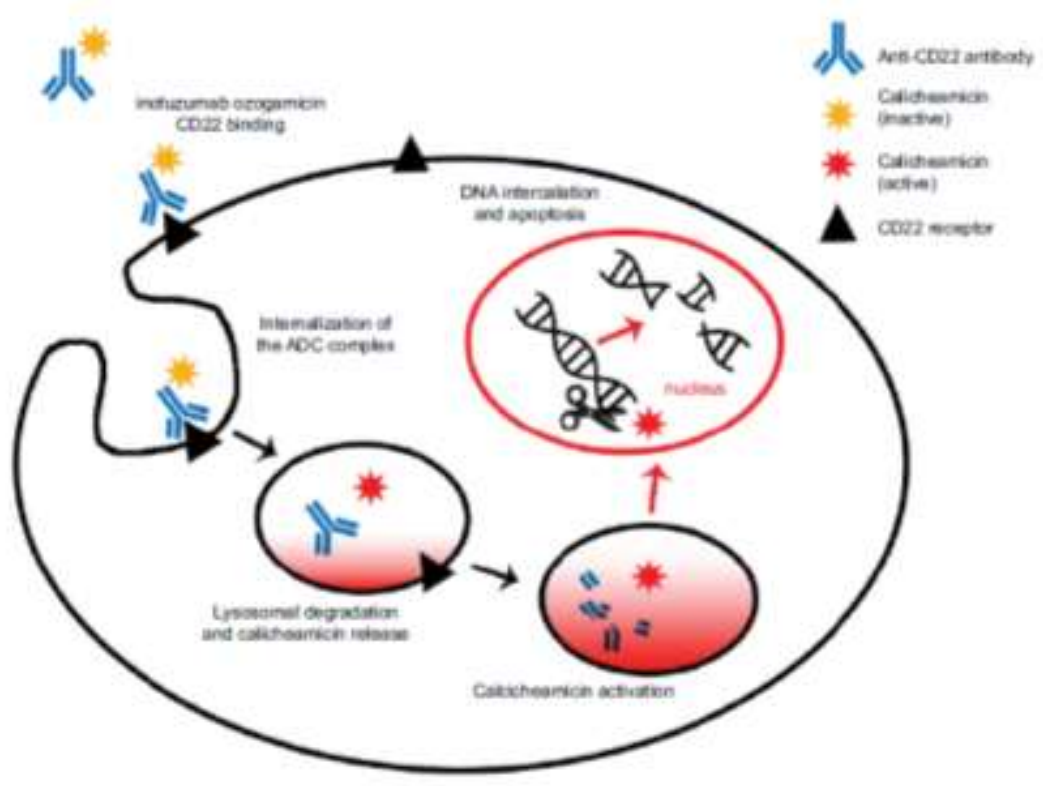

Penelitian Terkait Inotuzumab Ozogamicin

Untuk keamanan dan efikasi obat, dilakukan Trial pada 326 pasien dewasa dengan LLA sel B yang relaps atau refrakter. Ditemukan adanya remisi komplit yang signifikan pada pemberian Inotuzumab Ozogamicin dibandingkan yang menggunakan kemoterapi standar. ${ }^{6}$ 
Tabel 3. Hasil TRIAL Inotuzumab Ozogamicin

\begin{tabular}{|c|c|c|c|c|c|c|}
\hline \multirow[b]{3}{*}{ Elficacy } & \multicolumn{6}{|c|}{$\begin{array}{l}\text { Inotuzumab Ozogamicin versus Chemotherapy }{ }^{3} \text { in Patients with Relapsed or Refractory B-Cell Precursor Acute } \\
\text { Lymphoblastic Leukemia }\end{array}$} \\
\hline & \multicolumn{2}{|c|}{ Complete remissiont } & \multicolumn{2}{|c|}{$\begin{array}{l}\text { Complete remission with incomplete } \\
\text { henatologic recovery }\end{array}$} & \multicolumn{2}{|c|}{$\begin{array}{l}\text { Complete remission/complete remission } \\
\text { with incomplete hematologic recovery }\end{array}$} \\
\hline & $\begin{array}{l}\text { Inotuzumab } \\
\text { azoganicin } \\
(N=109)\end{array}$ & $\begin{array}{l}\text { HIDAC, FLAG, or } \\
\text { MXN/Ara-C } \\
(\mathbb{N}=109)\end{array}$ & $\begin{array}{l}\text { Inotuzumab } \\
\text { azogamicin } \\
(M=109)\end{array}$ & $\begin{array}{l}\text { HIDAC, FLAG, or } \\
\text { MON/Ara-C } \\
(\mathbb{N}=109)\end{array}$ & $\begin{array}{l}\text { Inotuzumab } \\
\text { ozogamicin } \\
(N=109)\end{array}$ & $\begin{array}{l}\text { HeAC, PLAG, or } \\
\text { MXN/Ara-C } \\
(M=109)\end{array}$ \\
\hline \multicolumn{7}{|c|}{ Responding patients } \\
\hline Pastents, N N N & $\begin{array}{c}39(35.8) \\
(96 \% \text { a. 26.8.45.5) }\end{array}$ & $\begin{array}{c}19(17.4) \\
\text { (95\% } \mathrm{Cl}, 10.8-25.9)\end{array}$ & $\begin{array}{c}49(45.0) \\
195 \% 0,35.4-54.8)\end{array}$ & $\begin{array}{c}13(11.9) \\
(95 \% \text { Cl, 6.5-19.5) }\end{array}$ & $\begin{array}{c}88(80.7) \\
(95 * \quad(7,72.1-87.7)\end{array}$ & $\begin{array}{c}32(29.4) \\
(95 \% \mathrm{Cl}, 21.0-38.8)\end{array}$ \\
\hline$P_{\text {value }}$ & \multicolumn{2}{|c|}{$<.0001$} & \multicolumn{2}{|c|}{$<, 0001$} & \multicolumn{2}{|c|}{$<.0001$} \\
\hline \multicolumn{7}{|c|}{ Duration of remission } \\
\hline Pafents, N & 39 & 18 & 45 & 14 & 84 & 32 \\
\hline Nadian, mo & 8.0 (95\% Cl, 4.9-10.A) & $4.9(95 \%, \mathrm{Cl}, 2.9-7.2)$ & 4.6 (195\% Cl, 3.7.5.7) & $2.9(95 \% \mathrm{C}, 0.6-5.7)$ & 5.4 (1PEK Cl, 4.2-8.0) & $3.5(95 \times \mathrm{Cl}, 2.8-6.6)$ \\
\hline \multicolumn{7}{|c|}{ MRD-negative status } \\
\hline Patents, N (\% & $\begin{array}{c}36(89.7) \\
96 \times 0,75.8-97.1\end{array}$ & $\begin{array}{l}6(31.6) \\
95 \times C 1,26-56.6\end{array}$ & $\begin{array}{l}34(69.4) \\
95 \%, \mathrm{Cl}, 4.6-81.7\end{array}$ & $\begin{array}{l}3(23.1) \\
95 \% \text { C }, 5.0-53.8\end{array}$ & $\begin{array}{c}69(78.4) \\
95 * 0.8 .4-86.5\end{array}$ & $\begin{array}{l}9(28.1) \\
95 \%, C l, 13.7-46.7\end{array}$ \\
\hline \multicolumn{7}{|c|}{ 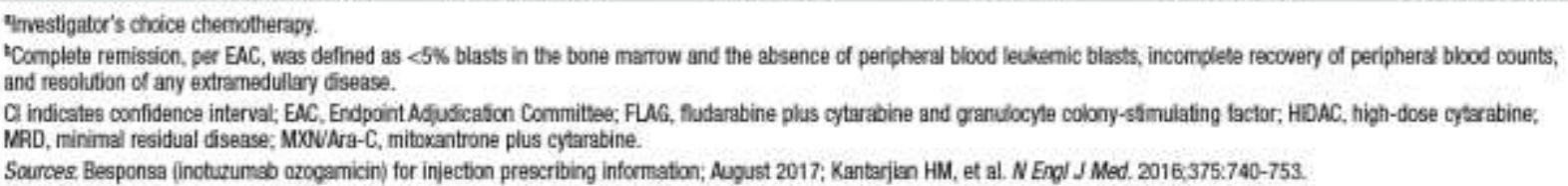 } \\
\hline
\end{tabular}

Sebanyak 35,8\% yang menerima Inotuzumab Ozogamicin mengalami remisi komplit dengan median 8 bulan dan sebanyak $17,4 \%$ yang menjalani kemoterapi standar mengalami remisi komplit dengan median 4,9 bulan. $^{8}$ Sebanyak $80,7 \%$ pasien yang menerima Inotuzumab Ozogamicin mengalami remisi komplit jika dibandingkan $29,4 \%$ pasien dengan kemoterapi standar $(p<0,001)$. Selain itu, pasien dengan terapi Inotuzumab Ozogamicin memiliki status Minimal Residual Disease (MDRD)negative yang lebih tinggi daripada kemoterapi standar. $^{9}$

Penelitian Elias 2016 menunjukkan Inotuzumab Ozogamicin cukup efektif digunakan pada pasien LLA usia tua kondisi refrakter atau relaps, yang penggunaan obatnya lebih terbatas.

Dilakukan penelitian 109 orang dengan LLA relaps atau refrakter usia $\geq 55$ tahun dibandingkan $<55$ tahun. Penelitian ini menunjukkan angka MDRD negative yang lebih tinggi pada pasien usia tua, sehingga Inotuzumab Ozogamicin cukup efektif pada pasien usia tua yang pemilihan obatnya terbatas. $^{10}$

Penelitian Daniel 2012 menunjukkan Inotuzumab Ozogamicin memiliki profil keamanan yang cukup baik, dari segi hematologic, gastrointestinal, fungsi hati dan risiko infeksi. Respon yang baik sebesar 32\% 
pasien mengalami remisi komplit dengan monoterapi Inotuzumab Ozogamicin. ${ }^{11}$

\section{Efek samping}

Efek samping Inotuzumab Ozogamicin adalah trombositopenia(51\%), neutropenia(49\%), risiko infeksi(48\%), anemia $(36 \%)$, leukopenia(35\%), lemas(35\%),perdarahan (33\%), demam(32\%), mual(31\%), sakit kepala(28\%), gangguan hati(26\%), nyeri abdomen(23\%), ataupun hiperbilirubinemia(21\%). ${ }^{9}$

\section{Dosis dan Penggunaan}

Inotuzumab Ozogamicin tersedia dalam bubuk lipofilik 0,9 mg dalam vial disertai dengan dilusi yang sesuai. Sebelum pemberian, sebaiknya pasien diberikan premedikasi seperti kortikosteroid, antipiretik dan antihistamin. Dosis regimen dalam 1 siklus dan selanjutnya disesuaikan dengan respon terapi. ${ }^{9}$ Dosis yang direkomendasikan Inotuzumab Ozogamicin adalah $1,8 \mathrm{mg} / \mathrm{m}^{2}$ per siklus, bisa diberikan dalam dosis terbagi pada hari ke-1 $\left(0,8 \mathrm{mg} / \mathrm{m}^{2}\right)$, hari ke-8 $\left(0,5 \mathrm{mg} / \mathrm{m}^{2}\right)$, dan hari ke-15 (0,5 $\mathrm{mg} / \mathrm{m}^{2}$ ) untuk siklus pertama . ${ }^{12}$

\section{Kesimpulan}

Inotuzumab Ozogamicin merupakan terapi baru yang disetujui oleh FDA tahun 2017. Secara trial dan beberapa penelitian terkait menunjukkan efikasi terapi yang baik. Namun tetap dibutuhkan penelitian berkelanjutan terkait penggunaan obat baru ini.

\section{Daftar Pustaka}

1. Kaushansky K, Lictman M, Prchal J, Levi M, Press O, Burns L,et al. Williams Hematology. $9^{\text {th }}$ Edition. United States. McGrawHill. 2016.

2. Sudoyo A W, Setyohadi B, Alwi I dkk. Buku Ajar IImu Penyakit Dalam. Edisi V.Jakarta. 2009.

3. Fauci AS, Kasper DL, Longo DL, Braunwald E, Hauser SL, Lameson JL, et al, editors. Harrison's Principles of Internal Medicine. $17^{\text {th }}$ ed. New York: McGraw-Hill. 2008.

4. Keohane E, Smith L, Walenga J. Rodak's Hematology. $5^{\text {th }}$ Edition. Elsevier. 2016.

5. Arber D, George T, Sojitra P. ASH-CAP Guidelines for the Diagnosis of Acute Leukemia. American Society of Hematology. 2017.

6. Food and Drug Administration. FDA Approves New Treatment for Adults with Relapsed or Refractory Acute Lymphoblastic Leukemia. US Department of Health and Human Services. 2017.

7. Uy N, Nadeaue M, Stahl M, Zeidan AM. Inotuzumab Ozogamicin in the Treatment of 
Relapsed/Refractory Acute B cell

Lymphoblastic Leukemia. USA: Journal of Blood Medicine. 2017.

8. Simon S. FDA Approves Besponsa (Inotuzumab Ozogamicin) for Acute Lymphoblastic Leukemia in Adults. American Cancer Society. 2017.

9. Fala L. Besponsa (Inotuzumab Ozogamicin) Approved for Adults with Relapsed or Refractory B-Cell Precursor Acute Lymphoblastic Leukemia. American Health and Drug Benefits.2018.

10.Elias J, Anjali S, Matthias S, Wendy S, Michaela L, Nocola G, et al. Efficacy and Safety of Inotuzumab Ozogamicin in Older
Patients with Relaps/Refractory Acute Lymphoblastic Leukemia Enrolled in the Global Phase 3 Randomized Controlled INOVATE Trial. Netherlands : European Hematology Association. 2016.

11.DeAngelo D, Stock W, Petersdorf S, Wang SL, Volkert A, Vandendries E, et al. Weekly Inotuzumab Ozogamicin in Adult Patients with Relapsed or Refractory CD22-Positive Acute Lymhoblastic Leukemia. American Society of Hematology. 2012.

12. Toich L. Besponsa Approved for Acute Lymphoblastic Leukemia. The American Journal of Pharmacy Benefits. 2017. 